\title{
The personalization of party politics in Western Europe (1985-2016): evidence from an expert survey
}

\section{Bruno Marino $^{1}$ (D) $\cdot$ Nicola Martocchia Diodati ${ }^{2}$ D $\cdot$ Luca Verzichelli $^{3}$ (D)}

Accepted: 26 July 2021 / Published online: 31 August 2021

(C) The Author(s) 2021

\begin{abstract}
The personalization of politics has been extensively studied from different angles and in different national contexts. Nonetheless, an easily comparable and longitudinal study of the personalization of politics at both the country and the party levels is still missing. In this article, we fill this gap by presenting data from an expert survey on the personalization of politics for around 110 parties and a series of Western European countries from the mid-1980s to the mid-2010s. The dimensions analyzed concern the impact of the personalization of politics in general elections, and also party leaders' room for maneuver in candidate selection, the definition of the party's policy-making agenda, and party leaders' intra-party control. Different reliability tests confirm the goodness of the data collected. At the same time, first descriptive analyses show that there has not been a homogenous diffusion of this phenomenon in Western Europe, and diverging personalization trends are present for different groups of countries or different dimensions of this phenomenon.
\end{abstract}

Keywords Personalization of politics $\cdot$ Expert survey $\cdot$ Parties $\cdot$ Leaders $\cdot$ Western Europe

\section{Introduction}

The personalization of politics is probably not a new phenomenon. To a large extent, the modern study of politics has grown by looking at the interactions between rulers and the whole political community. Nonetheless, in the past few decades, the study of the personalization of politics has been at the center of lively scholarly interest.

Luca Verzichelli

luca.verzichelli@unisi.it

1 Department of Political and Social Science, University of Bologna, Strada Maggiore 45, 40125 Bologna, Italy

2 Milan, Italy

3 Department of Social, Political and Cognitive Studies, University of Siena, via Mattioli 10, 53100 Siena, Italy 
Different aspects of this phenomenon have been investigated: the importance of leaders in the media (Farrell 1996; Mughan 2000; Kriesi 2011; Langer and Sagarzazu 2018); the power of party leaders (Blondel 1987; Blondel and Thiébault 2010) and chief executive leaders (Samuels and Shugart 2010); the increasing centrality of individual candidates in general elections (Renwick and Pilet 2016); the power of leaders in party organizations (Blondel and Thiébault 2010; Schumacher et al. 2013; Schumacher and Giger 2017). These are the subjects of just a handful of (more or less) recent studies focusing on the personalization of politics. Such variety should not be surprising. Indeed, the personalization of politics should be considered as a multifaceted concept (Rahat and Sheafer 2007; Adam and Maier 2010; Karvonen 2010; Balmas et al. 2014; Rahat and Kenig 2018).

In this contribution, we stick to the definition by Karvonen (2010, p. 4), according to whom the 'personalization hypothesis' states that 'that individual political actors have become more prominent at the expense of parties and collective identities.' Such a definition has the advantage of being very simple, encompassing, and extremely similar to other scholarly definitions (Rahat and Sheafer 2007, p. 65, Adam and Maier 2010, p. 213, Balmas et al. 2014, p. 37).

In this article, we present fresh data on the evolution of the personalization of politics in Western Europe between 1985 and 2016, from both a country- and a party-related perspective, using an expert survey (PoPES, Personalization of Politics Expert Survey) devised to tackle two specific areas of research: the impact of the personalization of politics, over time, in different countries and the importance of leaders within political parties.

Two main aims have triggered this research. The first one is to put forward a comprehensive dataset of this phenomenon in Western Europe, test data reliability, and describe them. Is it true that the personalization of politics is on the rise everywhere and with the same scope? Do different 'faces' of this process show diverse levels of variation over time and across countries? Some studies on the personalization of politics present data on just one or a few countries, while others put forward data related to different sides of this phenomenon, as already shown in the literature (Karvonen 2010; Rahat and Kenig 2018).

In contrast, PoPES data could allow researchers to analyze the evolution of the personalization of politics for a number of countries and around 110 Western European parties between the mid-1980s and the mid-2010s. Our effort is in line with the first 'core task' advocated by Adam and Maier for a research agenda on the personalization of politics, namely, to 'improve our ability to describe and measure the degree and development of personalization' (Adam and Maier 2010, p. 233 [italics in original]).

Moreover, three of the four questions of the PoPES that we present here focus on party leaders. Indeed, party leaders have increasingly been considered central actors in the evolution of personalized or presidentialized politics (Poguntke and Webb 2005a; Blondel and Thiébault 2010; Balmas et al. 2014; Musella and Webb 2015; Costa Lobo 2018; Musella 2018). For instance, one of the areas of research discussed by Poguntke and Webb (2005b, p. 5) is the 'increasing leadership power resources and autonomy within the party.' Despite this interest, it has recently been argued that 'there is a lack of integrated studies aiming to understand leaders' (Costa 
Lobo 2018, p. 5). Therefore, the focus on party leaders might help fill another gap in the literature, possibly with the help of other studies on the personalization of politics, such as that by Rahat and Kenig (2018).

Then, a second aim behind the PoPES is to facilitate scholars in devising foreseeable avenues of research. For instance, Adam and Maier (2010, p. 233) have called for research to understand the causes and consequences of the personalization of politics. We contend that, by using PoPES data, researchers could understand the mechanisms behind the personalization of politics ${ }^{1}$ with a great level of cross-time, cross-country, and cross-party comparability. Additionally, it could also be possible to understand the impact of the personalization of politics in diverse arenas (Costa Lobo 2018), possibly considering the reservations of some critical accounts on the effects of this phenomenon for democratic politics (Adam and Maier 2010, pp. 220-223, Rahat and Kenig 2018, pp. 208-220; 262-264).

All in all, this article addresses the puzzle of the personalization of politics from a genuinely empirical viewpoint. In "From concepts to variables: devising the expert survey" section, our goal is to provide a fine-tuned treatment of the concept and introduce our proposal, based on the expert survey we launched in 2017 (the PoPES). "The PoPES questions" section presents four expert survey questions and discusses their relevancy. Then, "A first view of the data: trends of the personalization of politics in Western Europe (mid-1980s-mid-2010s)" section shows a first descriptive analysis of the data collected. Conclusions follow.

\section{From concepts to variables: devising the expert survey}

As presented above, personalization is related to several faces of politics. However, the study of this concept still suffers from a structural shortcoming: different authors have focused on (partly or entirely) different aspects of the phenomenon, ${ }^{2}$ bringing about what has been called a 'conceptual and methodological muddle' (Rahat and Kenig 2018: 116; citing Van Aelst et al. 2012). Therefore, building an indicator of personalization with a high indicating portion is quite tricky. Let us imagine that we wanted to estimate the personalization of politics in a given general election. We could do so in several ways, by counting the number of times the names of the leaders appear on newspapers' titles, measuring the saliency of topics related to the leaders during the electoral debates, and the like. Although all these measurements attempt to estimate the degree of personalization in a given general election, they measure different elements of the same underlying concept. Thus, it is very likely that their estimation will differ substantially, and this represents a severe flaw for comparative empirical analyses (see the discussion in Van Aelst et al. 2012).

\footnotetext{
1 See a discussion on such causes in Adam and Maier (2010, pp. 234-238) and Rahat and Kenig (2018, pp. 125-131).

${ }^{2}$ See, for instance, the extensive discussion in Karvonen (2010).
} 
Moreover, there is a second problem: different authors have focused on different countries and different periods, as extensively shown by Karvonen (2010), thus making cross-country and diachronic comparisons much more difficult. ${ }^{3}$

So, it is central to have a cross-country, cross-time, and homogeneous measurement of this phenomenon. Following many authors (Benoit and Laver 2006; O'Malley 2007; Nanou et al. 2017), an adequate tool to reach this goal is an expert survey. Indeed, 'the great virtue of an expert survey is that it sets out to summarize the judgments of the consensus of experts on the matters at issue, and moreover to do so in a systematic way' (Benoit and Laver 2006, p. 9 [italics in original]). Therefore, a compound empirical phenomenon, such as the personalization of politics, can be approached by a focused attempt of data gathering able to consider its different dimensions. Indeed, '[a] common factor in [the] applications of expert judgment is its use to estimate quantities that are difficult or even impossible to observe directly' (Benoit and Laver 2006, p. 72). For instance, '[e]xpert surveys are an increasingly important tool for studying European integration. They have been shown to produce sufficiently valid and reliable results and they offer greater opportunities for researchers to study topics for which there is scarce information' (Nanou et al. 2017, p. 682 [italics added]). We contend expert surveys can offer a significant contribution to comparative research also in the analysis of the personalization of politics.

Let us first consider the longitudinal dimension of the PoPES. We focused on the period from the mid-1980s to the mid-2010s to obtain information on approximately 30 years, where significant transformations were brought about in party organizations (Katz and Mair 1994; Scarrow et al. 2017), political elites (Cotta and Verzichelli 2014), and party systems (Emanuele and Chiaramonte 2018). Given our interest in the diachronic perspective of the personalization of politics, the reliability of experts' answers has also been tested from a temporal viewpoint (see "The PoPES questions" section and Online Appendix B), and we show such reliability was not affected by the time passed from the events that experts had evaluated. In other words, the variability of experts' answers did not depend on answering questions on-say-2016 or 1996.

On case selection, we have included all main Western European countries: Austria, Belgium, Denmark, France, ${ }^{4}$ Finland, Germany, Greece, Iceland, Ireland, Italy, the Netherlands, Norway, Portugal, Spain, Sweden, Switzerland, and the United Kingdom. Turning to parties, to make the survey as inclusive as possible, but also avoid putting too much pressure on experts by asking them questions about very small parties, we have focused on the most relevant political formations. We have

\footnotetext{
3 This problem has been partly solved by Rahat and Kenig (2018). Nonetheless, the authors themselves acknowledge the limitations of their data (Rahat and Kenig 2018, pp. 8; 138; 194), which in any case, are available only at the country level, while PoPES data are also available for a number of Western European parties. Finally, while Rahat and Kenig's data have only a single value of personalization/depersonalization/no change over time (for each indicator they consider), PoPES data are available for many points in time relevant number of countries and parties.

4 To be consistent with the questions asked for other countries and facilitate comparisons, we focus on answers related to French parliamentary elections when dealing with France (where we have considered the head of the extra-parliamentary organization).
} 
implemented two criteria for the inclusion of parties in a given election ${ }^{5}$ : having reached at least $5 \%$ of the votes in at least one election between the mid-1980s and mid-2010s and having reached at least $1 \%$ of the votes in the specific election under consideration. This second criterion was devised to avoid asking respondents questions on parties that were (became) too small to be considered relevant actors of a system. All in all, around 110 Western European parties have been included in the PoPES. ${ }^{6}$

We have relied on general elections as temporal anchors, given that the personalization of politics can hardly be considered a static concept (Rahat and Kenig 2018, pp. 124-125). How can we evaluate its evolution over time? Two main roads could have been followed: we could have relied on yearly questions. Alternatively, we could have focused on questions encompassing a longer period. We opted for the latter path.

Indeed, it would have been challenging to ask experts to rate each country (or each party) for each of the (approximately) 30 years constituting the timespan of our analysis. ${ }^{7}$ Moreover, the choice of relying on temporal periods-instead of a yearby-year focus - is a path already taken by other existing expert surveys, such as the Chapel Hill Expert Survey (Bakker et al. 2015).

Let us underline PoPES data would allow researchers to focus on country- and party-level data on the personalization of politics, focusing on its evolution for some 30 years. As a result, our data can fit different research aims: analyzing periods, groups of parties, groups of countries, and so forth.

Clearly, it was impossible to focus on every aspect of the personalization of politics (e.g., see the dimensions or indicators included in Balmas et al. 2014; Pruysers et al. 2018; Rahat and Kenig 2018): some of these aspects have not been included in this first version of the survey presented in this article. To begin with, despite our focus on party leaders, ${ }^{8}$ we do not explicitly refer to the presidentialization of politics (Poguntke and Webb 2005a, b): the former is a multidimensional process, which has undergone a vivid theoretical and empirical debate (Dowding 2013a, b; Webb and Poguntke 2013) and probably does not perfectly fit our purposes.

This does not mean that the presidentialization of politics cannot give us valuable insights. On the contrary, while the focus of the presidentialization of politics on party leaders (and Prime Ministers) is considered by some authors as a weakness (Pruysers et al. 2018), for us, it is actually a strength, given we also mainly focus on

\footnotetext{
5 Also see, among others, different thresholds discussed in the literature by Janda (1980), Mainwaring and Scully (1995), Kölln (2016), Chiaramonte and Emanuele (2017).

${ }^{6}$ Online Appendix A reports the full list of parties.

${ }^{7}$ Let us give a brief example. As we show later in this article, single political parties are the unit of analysis in three out of the four questions composing our expert survey. So, in a party system with five parties under examination, asking experts to rate each party in each year would have meant asking respondents to fill 450 questions (five parties * 30 years * three questions specifically targeting each single party), a quite unbearable task.

${ }^{8}$ This is why we have not considered some dimensions related to the so-called 'decentralized personalization' (Balmas et al. 2014; see also later in the article), such as the behavior or attitudes of party candidates for general elections and MPs (e.g., see De Winter et al. 2021; Wauters et al. 2021).
} 
party leaders, at least in this first version of the expert survey. Some book chapters of the edited book by Poguntke and Webb $(2005 \mathrm{a}, \mathrm{b})$ are extremely useful for this article, as we show in "A first view of the data: trends of the personalization of politics in Western Europe (mid-1980s-mid-2010s)" section.

Nonetheless, despite the common focus on party leaders, we do not focus on Prime Ministers or executives (like the presidentialization of politics), nor do we imply there might have been a shift towards the 'presidentialization pole' in PoPES countries, even if remaining within the boundaries of the parliamentary regime, as instead argued by Poguntke and Webb (2018). Finally, there is considerable debate in the literature whether the presidentialization of politics shall be considered a subset of the wider personalization of politics (Balmas et al. 2014; Costa Lobo 2018; Poguntke and Webb 2018; Rahat and Kenig 2018). All in all, we prefer playing on the safe side and acknowledging the importance of the presidentialization of politics for our framework of research, despite remaining on the safer shores of the personalization of politics.

Moreover, following the procedure by Rahat and Kenig (2018, pp. 34-38), we briefly deal with some research areas not touched by the PoPES. First, media-related personalization (e.g., the presence of leaders on newspapers, TV, and so forth), since other analytic instruments have been proficiently used, such as the analysis of newspaper headlines and articles or political advertisements (Kriesi 2011; Balmas et al. 2014). Second, the personalization of electoral systems, given the encompassing research by Renwick and Pilet (2016), can already give us many useful insights into this matter. ${ }^{9}$ Third, and finally, the personalization within the institutional or governmental leadership. As shown later, three out of the four questions reported in this article have the political party in the general election as the unit of analysis: so, we wanted to cover the largest possible set of cases, with no bias or restricted focus on some specific governmental leader or party. Moreover, many pieces of research have already dealt with the increased power of institutional or governmental leaders (Strøm et al. 2003; O’Malley 2007; Dowding and Dumont 2009).

Let us reiterate that certain selection among the several possible facets of personalization was necessary to avoid asking experts too many questions. We do hope that the content of this article would encourage scholars to investigate other areas of research related to the personalization of politics in future studies, possibly starting from our expert survey.

It is now time to delve deeper into the expert survey itself. The next question presents the survey questions on which we focus in this article and discusses their relevance for our understanding of the (intra-party) personalization of politics.

\footnotetext{
9 Additionally, some scholars include the opening of leader selection rules within the broader set of 'institutional personalization' (e.g., see Balmas et al. 2014 or Rahat and Kenig 2018; see further discussion in Musella 2018). We have not focused on this aspect given there are already much available data on the topic for Western European parties-let us just mention the edited book by Pilet and Cross (2014) or the collective effort of the Political Party Database Project (PPDB) (Scarrow et al. 2017).
} 


\section{The PoPES questions}

The formulation of the first question (Personalization in General Elections) was as follows:

How would you evaluate the overall impact of the personalisation of politics in each of the following General Elections? Please rate such impact on a 1-10 scale, where 1 means "very low impact" and 10 means "very high impact."

Then, in this article, we focus on three subsequent questions, related to party leaders (Personalization in Candidate Selection; Personalization in Policy-Making; Personalization in Party Control), were:

Moreover, how would you evaluate the autonomy of party leaders in selecting candidates for General Elections? Please rate leaders' autonomy on a 1-10 scale, where 1 means "very low autonomy" and 10 means "very high autonomy".

How would you evaluate the autonomy of party leaders in defining the policy-making agenda of the party? For each of the following parties, please rate leaders' autonomy on a 1-10 scale, where 1 means "very low autonomy" and 10 means "very high autonomy".

Finally, how would you rate the control that party leaders have on party organisation? For each of the following party leaders, please rate leaders' control on a 1-10 scale, where 1 means "very low control" and 10 means "very high control."

Concerning the first question (Personalization in General Elections), a primary aim of the survey was to obtain an overall insight on the personalization of politics in each country for each general election, without introducing any bias in respondents' reasoning. A logical critique might be that asking such a general question would be incompatible with the fact that different authors have differently operationalized the personalization of politics, exactly because of the multifaceted nature of this concept. Nonetheless, it is just because of this nature that we have decided not to focus on a single operationalization but to rely on experts' knowledge of the matter (Benoit and Laver 2006, pp. 73-74) to grasp a comprehensive measure of the personalization of politics. Obviously, reliability tests are needed to verify the reliability of the data we have collected, and we show the results of such tests in "The PoPES questions" section and Online Appendix B.

Let us move to the three party-leader-related questions. Starting from Personalization in Candidate Selection, more and more scholars have focused on such fundamental function performed by political parties (Gallagher and Marsh 1988; Hazan and Rahat 2010), especially_but not exclusively-on its impact on legislative behavior (Andeweg and Thomassen 2011; Spies and Kaiser 2014). Additionally, Blondel and Thiébault (2010) underline the importance of understanding the role of party leaders in candidate selection, because '[t]he power of candidate selection provides leaders with a tool enabling them to exercise total control on MPs' (Blondel 
and Thiébault 2010, p. 97) and this should not be surprising, given the importance of the changes in the opportunity structures of political recruitment (Norris 1997). From the opposite viewpoint, Balmas et al. (2014, p. 37) discuss the importance of candidate selection for the so-called 'decentralized personalization. ${ }^{10}$ Therefore, understanding the role of party leaders in selecting candidates for general elections can give us not just valuable insights into such 'secret garden' (Gallagher and Marsh 1988) of intra-party politics, but also allow us to understand the extent to which party leaders can control and influence such an important facet of political parties like Members of Parliament. ${ }^{11}$

Then, the autonomy of party leaders in defining the policy-making agenda of their parties and the control that such leaders have in party organizations (respectively, Personalization in Policy-Making and Personalization in Party Control) have been widely considered as extremely important, from several points of view. Indeed, starting from the latter question, Blondel and Thiébault (2010) argue that the power of leaders within political parties constitutes a fundamental aspect to investigate to study the personalization of politics. Additionally, Blondel and Cotta (2000) underline the importance of the overall degree of control over the party machinery as a crucial element fostering different outcomes in terms of party government patterns. Moreover, from a wider viewpoint, two party-related areas of research in Webb and Poguntke (2005, p. 338) are the '[s]hift in intra-party power to benefit of leader' and the '[i]ncreasing autonomy of party leader from intra-party power-holders,' so, also scholars focusing on the presidentialization of politics might find our data of great use. Then, also authors analyzing the personalization of politics from diverse perspectives underline the importance of leaders' control of their organization, such as Balmas et al. (2014), who discuss the so-called 'centralized institutional personalization,' meaning that (party) leaders' position has been strengthened. Finally, Schumacher et al. (2013) and Schumacher and Giger (2017) focus-from a different angle - on a crucial differentiation between leader-dominated and activist-dominated political formations in shaping parties' policies (and, therefore, in affecting parties' policy-making).

The two works by Schumacher and colleagues have been quite helpful for building our questions because their operationalization of leaders' control of political parties constitutes one of the few and most useful attempts to empirically grasp one of the faces of the personalization of politics. However, for a tighter look at such a concept, we have created two separate questions: one related to the general control of the party organization by its leader and one related to leaders' autonomy in defining the policy-making agenda of the party. Finally, Blondel and Thiébault (2010) argue that the role of party leaders in setting the policy priorities of their parties is an important facet to be investigated in political parties.

\footnotetext{
10 'Decentralized personalization means that power flows downwards from the group to individual politicians who are not party or executive leaders (e.g. candidates, members of parliament, ministers)' (Balmas et al. 2014, p. 37).

11 See the related importance of party MPs for the 'Party in Public Office' 'face' of political parties (Katz and Mair 1993).
} 
Table 1 Experts' response rate

\begin{tabular}{|c|c|c|c|}
\hline Country & $\begin{array}{l}N \text { experts } \\
\text { contacted }\end{array}$ & $\begin{array}{l}N \text { expert } \\
\text { respondents }\end{array}$ & $\begin{array}{l}\text { Percentage } \\
\text { of respond- } \\
\text { ents }\end{array}$ \\
\hline Austria & 20 & 9 & 45 \\
\hline Belgium & 35 & 11 & 31.4 \\
\hline Denmark & 16 & 7 & 43.7 \\
\hline Finland & 11 & 5 & 45.4 \\
\hline France & 33 & 15 & 45.4 \\
\hline Germany & 38 & 17 & 44.7 \\
\hline Greece & 15 & 11 & 73.3 \\
\hline Iceland & 7 & 4 & 57.1 \\
\hline Ireland & 11 & 9 & 81.8 \\
\hline Italy & 20 & 13 & 65 \\
\hline Netherlands & 25 & 7 & 28 \\
\hline Norway & 16 & 4 & 25 \\
\hline Portugal & 15 & 8 & 53 \\
\hline Spain & 20 & 14 & 70 \\
\hline Sweden & 18 & 3 & 16.7 \\
\hline Switzerland & 17 & 11 & 64.7 \\
\hline United Kingdom & 22 & 7 & 31.8 \\
\hline Total & 339 & 159 & 46.9 \\
\hline
\end{tabular}

Let us briefly present data on the pool of experts. We contacted a number of political scientists in each country who are experts in comparative politics. Different roads have been taken to reach a sufficiently high number of political scientists for each country: we checked some sources (e.g., National Election Studies' websites, the project MAPP's website ${ }^{12}$ ) to extract people to be contacted, then verified their academic knowledge of party- or election-related matters and included in the final list just those scholars with renowned expertise in the field. Subsequently, we analyzed the existing literature in depth to increase the number of country experts, even in this case, including the scholars with recognized expertise. Finally, a 'snowball' strategy asking to identify further experts was implemented: we were pointed to an additional number of country experts with competence in the related matters.

Let us now move to the analysis of the reliability of the experts' answers. This constitutes a necessary starting point of the analysis of PoPES data.

\footnotetext{
${ }^{12}$ See Van Haute et al. (2018)
} 
A first point from Table 1 is the quite satisfactory average response rate of the PoPES (46.9\%), which is in line with (or better than) the response rate of some wellknown expert surveys (Laver and Hunt 1992; Ray 1999; Druckman and Warwick 2005; Benoit and Laver 2006; Bakker et al. 2015; Borz and De Miguel 2019).

Table 1 also reports, for each country, ${ }^{13}$ the number of experts contacted, and following Benoit and Laver (2006, pp. 82-83), the number and the percentage of experts who responded. ${ }^{14}$ In only four countries out of 17 , less than $30 \%$ of the experts responded, a threshold that can be considered fairly acceptable, compared with other expert surveys: for instance, the response rate for the expert survey by Druckman and Warwick $(2005$, p. 22) was $22.3 \%$, and the response rate for that by Borz and De Miguel (2019, p. 1510) was 'almost 18 per cent.'

We have also performed a series of reliability tests (see Online Appendix B) that confirm the reliability of the experts' answers. One of the most important results of such tests has been the lack of a statistically significant effect of time measured in years passed between the year of a given general election and 2017 (the year in which the survey was delivered).

Let us now turn to the discussion of PoPES data. In "A first view of the data: trends of the personalization of politics in Western Europe (mid-1980s-mid-2010s)" section, we present the trends - if any - that can be detected concerning the personalization of politics and its different faces in Western Europe between the mid-1980s and the mid-2010s.

\section{A first view of the data: trends of the personalization of politics in Western Europe (mid-1980s-mid-2010s)}

This section presents the trend figures for the different faces of the personalization of politics in Western Europe over time. The figures in this section indicate that a homogeneous trend cannot be detected, in line with some other analyses of the personalization of politics (e.g., Rahat and Sheafer 2007, p. 66). Conversely, some crucial turning points can be identified. Figures 1, 2, and 3 group countries from a loose geographical viewpoint: Southern Europe (Portugal, Spain, Italy, and Greece); Continental Europe (France, Belgium [Flanders], Belgium [Wallonia], the Netherlands, Germany, Switzerland, and Austria); finally, Ireland, United Kingdom, and Scandinavia (Iceland, Denmark, Norway, Sweden, and Finland).

\footnotetext{
13 The Belgian experts could complete the questionnaire only for the Walloon parties, only for the Flemish ones, or also for both. The reasons behind our choice are related to the peculiar structure of the Belgian party system: for the main party families (Green, Socialist, Liberal, and Christian-Democratic), there exist both a Walloon party and a Flemish party, and there are (or have been) some parties representing specific communities (Flemish ones or Walloon ones), (e.g., see Emanuele 2018, p. 161-163; 242). Nonetheless, we have not a priori distinguished between experts for Walloon or Flemish parties. One of the reasons behind this choice is that many experts have worked (work) in Brussels. Therefore, given the peculiar characteristics of the Brussels area for the Belgian party system [where both Flemish and Walloon parties compete for general elections (Emanuele 2018, p. 242)], we have preferred not to insert bias into the Belgian questionnaires.

14 Experts completed the questionnaire on the online platform Survey Monkey.
} 


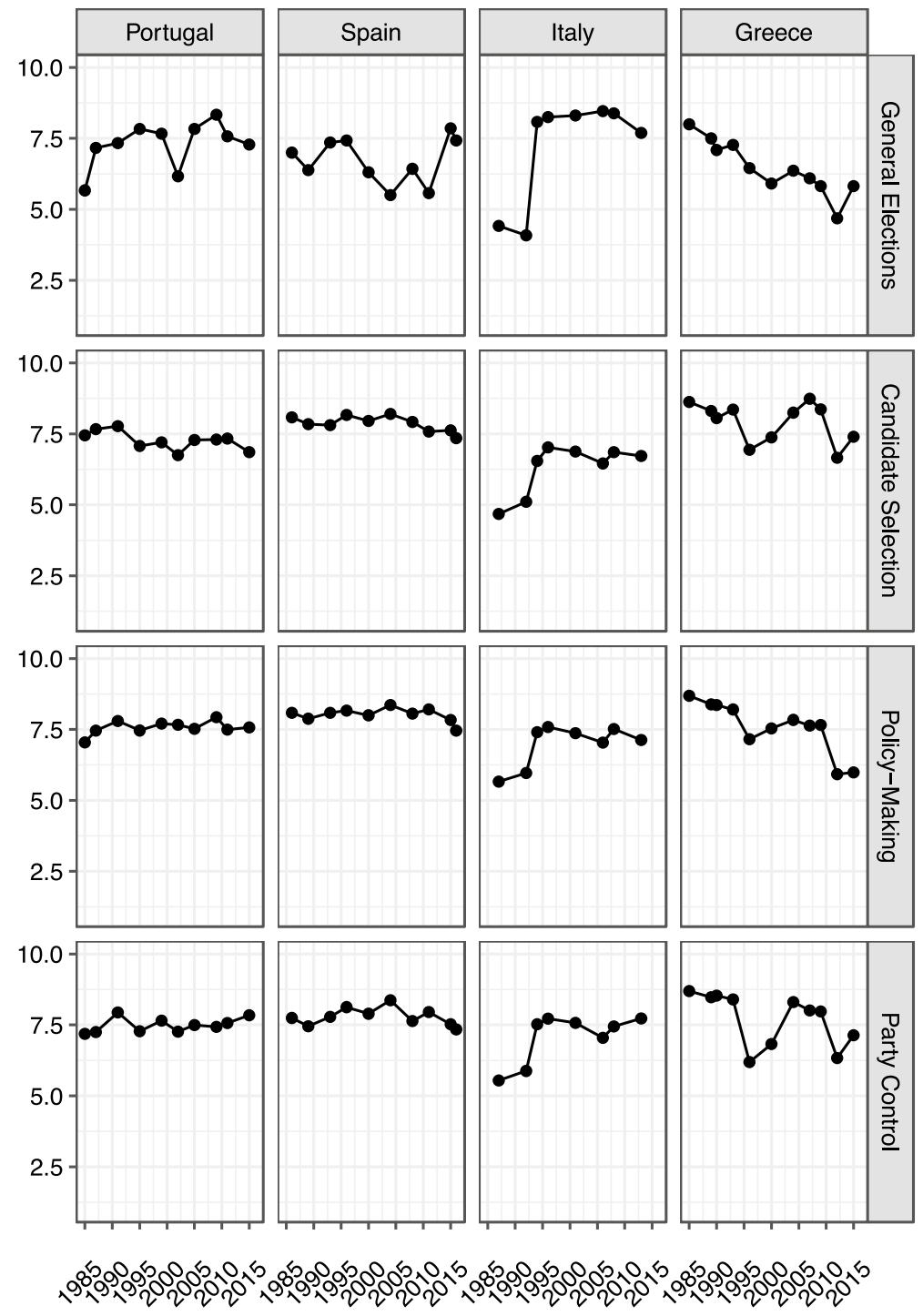

Fig. 1 Trends of the four dimensions of the personalization of politics (experts evaluation), Southern Europe (1985-2016). For all dimensions apart from the first one (first row), an average weighted by party votes in general elections has been calculated

We divide the comments to the figures into two parts: first, we comment data for each of the four PoPES dimensions, starting from the country-level one (first row of Figs. 1, 2, and 3) and then moving to the three party-level dimensions (second, third, and fourth rows of Figs. 1, 2, and 3). Subsequently, there is a different discussion, where we comment on trends for the three country groups presented above. 


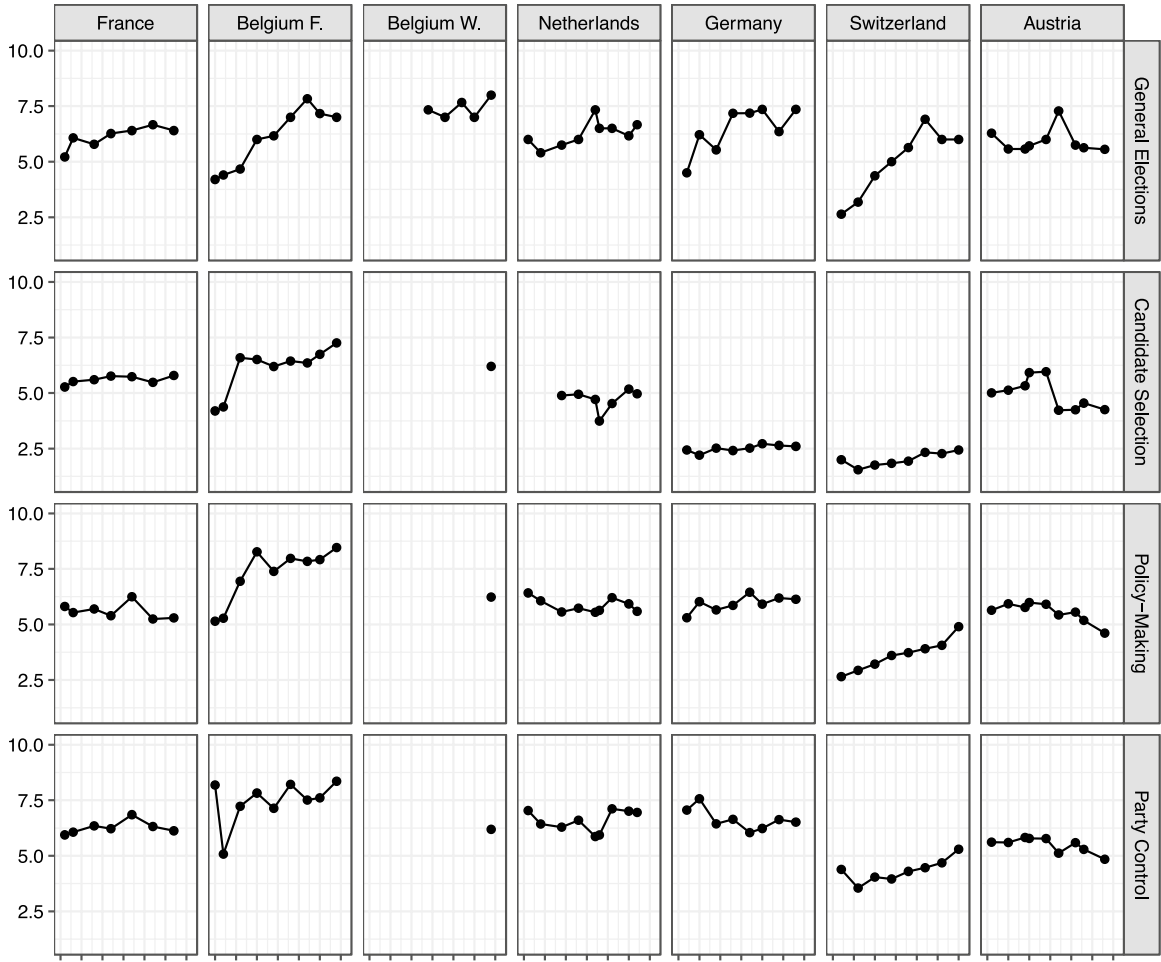

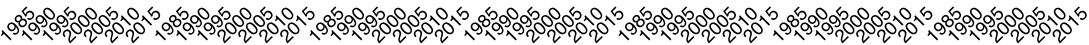

Fig. 2 Trends of the four dimensions of the personalization of politics (experts evaluation), Continental Europe (1985-2016). For all dimensions apart from the first one (first row), an average weighted by party votes in general elections has been calculated

Let us then start with the Personalization in General Elections. Figures 1, 2, and 3 show that, in Nordic countries, Denmark and Finland show an increasing trend, while Norway is characterized by overall stability and Sweden by a sudden increase in the mid-2000s (see Aylott and Bolin 2007) which nonetheless results in a general decrease if we look at the entire period under study. Finally, Iceland shows a decreasing trend as well between the mid-1980s and the mid-2010s. Passing to continental Western European countries, France and the Netherlands show a somewhat moderately increasing pattern. Germany (to a lesser extent), Belgium (here presented by separately considering Flanders and Wallonia), and Switzerland reveal an overall robust increasing trend in the impact of personalization. While partial stability can be detected in Ireland and the United Kingdom, in Southern Europe, three different patterns clearly emerge: Portugal and Spain show increasing-albeit extremely varied-trends, while Greece shows a noticeable decreasing movement, and Italy emerges as the country with an increasing trend and with the sharpest upward change, coinciding with the 1994 general election and the inception of Silvio Berlusconi's political venture-e.g., see Mazzoleni (1996). 


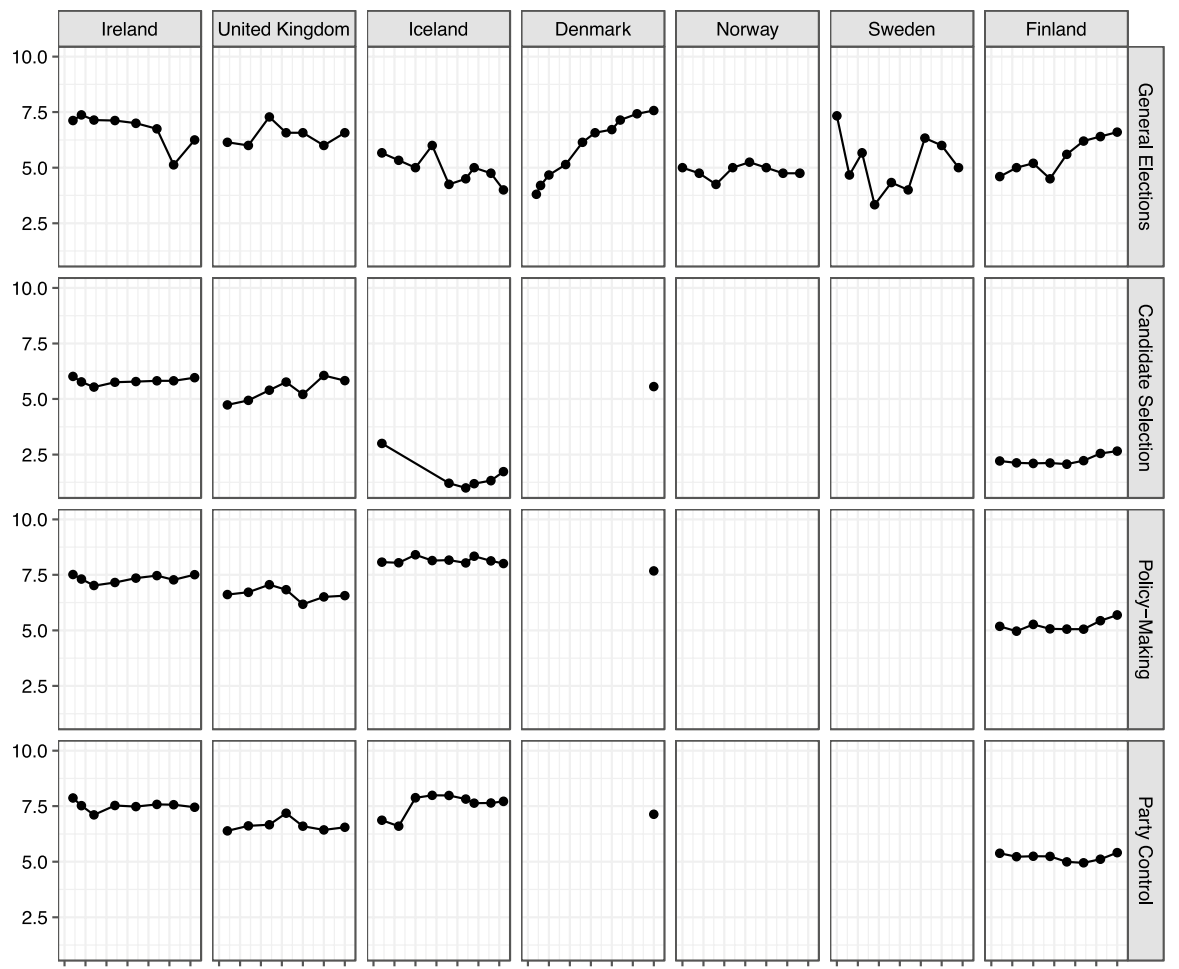

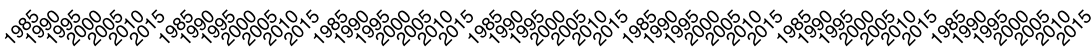

Fig. 3 Trends of the four dimensions of the personalization of politics (experts evaluation), Ireland, United Kingdom, and Scandinavia (1985-2016). For all dimensions apart from the first one (first row), an average weighted by party votes in general elections has been calculated

Moving to the party-related questions, the boxes in Figs. 1, 2, and 3 for the Personalization in Candidate Selection show that, unfortunately, due to country experts' lack of answers, there is much missing information. Therefore, some trend graphs could not be produced (for Norway and Sweden) or show only a limited number of values (Belgium Wallonia, Denmark, and the Netherlands). A first element of interest is that, in general, there is a lower variability over time when the Personalization in Candidate Selection is considered vs. the Personalization in General Elections, albeit with interesting differences. Let us take the Italian and Swiss cases: these two countries have quite shifting trends concerning the evaluation by experts of the personalization of politics in general elections. Conversely, when we investigate a more specific facet of personalization, the autonomy of party leaders in selecting candidates for general elections, more stable trends emerge for Switzerland but not for Italy. In some other countries, such as Finland, Germany, and the Netherlands, not only is party leaders' autonomy in candidate selection lower than the more general impact of the personalization of politics, but the former also shows more constant values - in other words, upwards or downwards trends cannot be easily detected. 


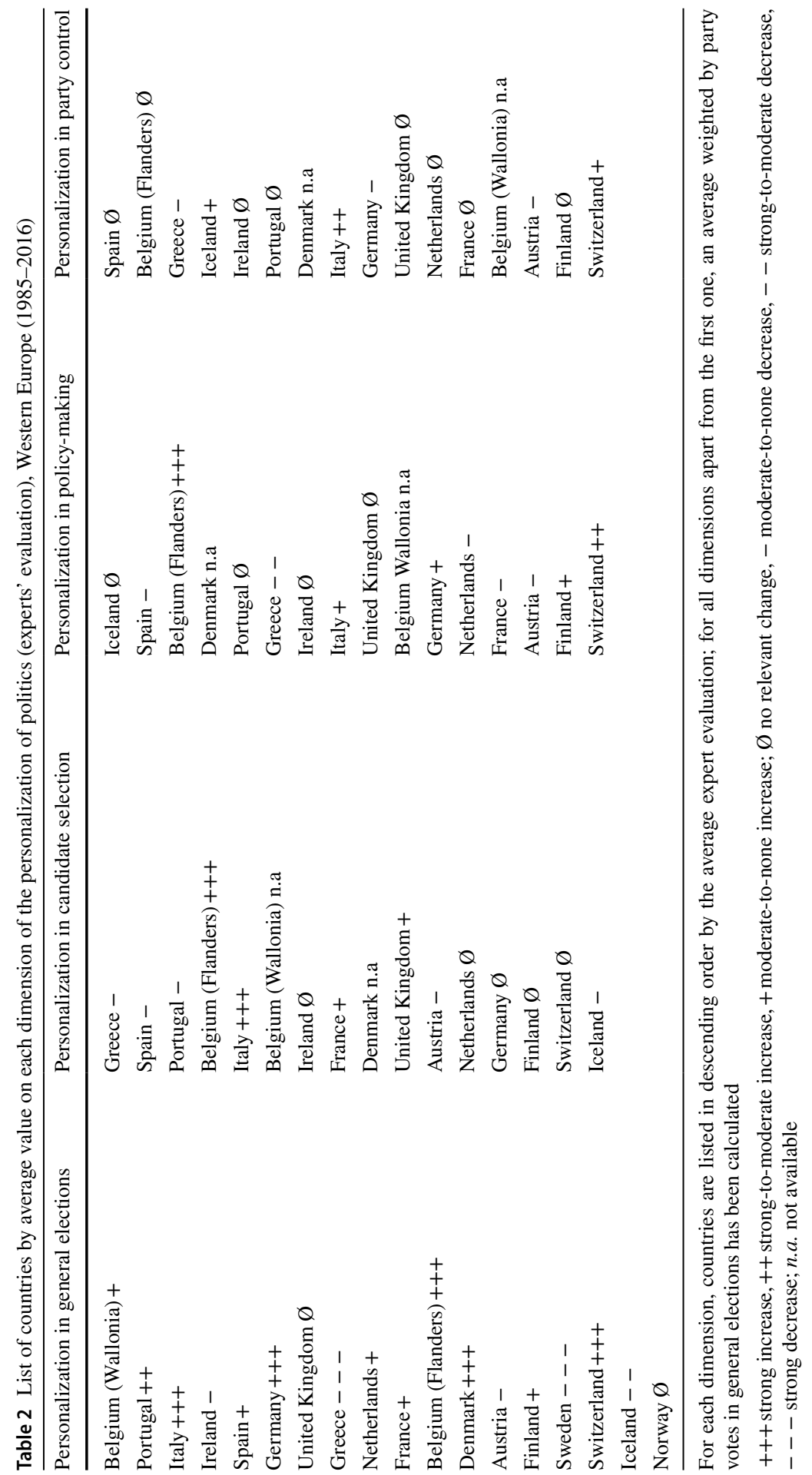


Then, on the Personalization in Policy-Making and the Personalization in Party Control, some countries show wavering changes: a first initial increasing phase is followed by a middle decreasing trend, followed again by an increase. An example is the United Kingdom pattern. A substantially less variable pattern is detectable in many other countries, notwithstanding some more varying cases, such as the Swiss and Belgian Flemish ones. Moreover, some countries have a very flattened evolution of the control of the party organizations by their leaders (Portugal, Spain, Ireland, and Finland), while more variable trends are evident for Austrian parties. Additionally, in Greece, after reaching the lowest point in the mid-1990s, the control of parties by their leaders starts rising in the mid-2000s (Pappas and Dinas 2006; Spourdalakis and Tassis 2006) and then follows a less stable trend.

If we separately look at Figs. 1, 2, and 3, interesting differences among the three country groups clearly emerge. To fully appreciate them, let us now have a broader look at the evolution of the different dimensions of the personalization of politics. By taking inspiration from the table presented by Webb and Poguntke (2005, pp. 338-339), Table 2 above reports a synthetic qualitative summary of the main trend for each country and each of the four dimensions we have investigated. More specifically, each country is positioned according to the average score given by experts for each dimension. For the three party-level questions (namely, the second, third, and fourth columns from the left), we have calculated an average weighted by parties' share of votes in general elections (see Online Appendix B for more details). Then, the + and - indicate the strength of the (upwards or downwards) trend for each country as evaluated by looking at Figs. 1, 2, and 3.

Starting with Southern Europe, these countries have, on average, high scores for each dimension of the personalization of politics we have investigated. Surely, there are differences between-say-Spain and Italy, but, on average, Southern European countries show quite high levels of the personalization of politics (as also shown by such countries' graphs in Fig. 1 above). Conversely, the trends of such countries are different if we look at the different dimensions of the PoPES: only for the Personalization in General Elections do we find three out of four countries having an upward movement over time (all but Greece). If we move to the party-level dimensions, almost all countries show a declining trend over time, except for Italy, the sole country in this group having upwards trends for all the personalization dimensions discussed in this article. The PoPES trends (also at the party level) up to the mid-2000s are similar to those reported for the increase in power and autonomy of Spanish and Italian parties up to the mid-2000s (Calise 2005; Van Biezen and Hopkin 2005; Webb and Poguntke 2005), while more evident differences are present for Portuguese parties (Costa Lobo 2005; Webb and Poguntke 2005).

Moving to Continental European countries (Fig. 2), a much more scattered picture emerges. Belgium (either Wallonia or Flanders) and Switzerland emerge among, respectively, the most and the least personalized polities (as also shown by Table 2). Nonetheless, the other countries included in this cluster (France, the Netherlands, Germany, Switzerland, and Austria) occupy diverse positions in Table 2 for the different PoPES dimensions. Moreover, in the party-level dimensions, but especially for the Personalization in Candidate Selection and Personalization in Party Control, there are almost all Continental European countries showing not just low 
average values (that is, a low position on each dimension's ranking in Table 2), but also small increases or decreases over time. The PoPES trends are compatible with those reported concerning the strengthening of Flemish party leaders, while this is not the case for the overall stable (if not slightly declining) trend for Dutch party leaders (Fiers and Krouwel 2005; Webb and Poguntke 2005). Conversely, a more complex picture emerges for German parties up to the mid-2000s (Poguntke 2005; Webb and Poguntke 2005).

Finally, let us comment on Fig. 3 and Table 2 for Ireland, the United Kingdom, and Scandinavia (Iceland, Denmark, Norway, Sweden, and Finland). Ireland stands out as one of the most personalized countries in this group, while Iceland and Finland seem to be the least personalized ones. Also here, apart from the Personalization in General Elections, many countries show negligible or absent trends of (increase or decrease in) personalization over time. PoPES data do not match those presented in the country reports on the presidentialization of Finnish parties (Paloheimo 2005; Webb and Poguntke 2005). Instead, UK data are in line with earlier research on the policy-making room for maneuver of British PMs (Blondel 1996) but less in line with more recent research on the presidentialization of politics in British politics, especially concerning the Conservative party (Heffernan and Webb 2005; Webb and Poguntke 2005). An interesting final element is that Ireland and the United Kingdom are the sole polities where three dimensions of personalization out of four show a negligible trend over time, with no marked increase or decrease.

A few other general takes derived from the reading of Table 2 deserve our attention. First, there is a group of countries that are consistently present in the top half of each dimension's ranking: Ireland, Portugal, Spain, Italy, and Greece. There is also a smaller group of countries consistently present in the bottom half of the ranking for each PoPES dimension: Switzerland, Finland, and Austria. We are not considering the trend, but simply the (weighted) average of each country in each dimension. So, we might imagine a sort of 'Southern European plateau' of personalization, because all the countries coming from this region show a quite high average for all dimensions of personalization (e.g., see considerations in Bosco and Morlino 2006). Interestingly, if we exclude Italy from the first group, all the 'high personalized' countries have a high position in the dimensions' ranking, but a downwards trend. Conversely, we do not find the opposite situation in the 'low personalized' countries: Switzerland, Finland, and Austria do not have an upwards trend. Instead, there are many cases of negligible upwards or downwards movements - and we come back to this point in a moment.

Second, just three countries show coherent trends for all the four PoPES dimensions: Italy has always a positive trend, while Greece and Austria always show a negative trend. All the other countries have at least one dimension showing a dissimilar trend compared to the other ones. We believe this is a further element showing the multifaceted nature of the personalization of politics: for almost all the polities included in this expert survey, there are different trends for different dimensions of personalization in Western Europe between the mid-1980s and the mid-2010s. This is not surprising, especially if one reads Pruysers et al. (2018) who quote a meta-analysis by Wauters et al. (2016) on 40 works on personalization. These works 'divide almost perfectly between those confirming empirically a growing 
Table 3 Country characteristics and experts' evaluation on trends in the Personalization in General Elections dimension

\begin{tabular}{|c|c|c|c|c|c|}
\hline Country features & & $\begin{array}{l}\text { Personalization in } \\
\text { general elections }\end{array}$ & $+/++/+++$ & $\varnothing$ & $-1--1---$ \\
\hline \multirow[t]{2}{*}{ Regime type } & (Semi-)Presidential & & 3 & & 3 \\
\hline & $\begin{array}{l}\text { Parliamentary/mon- } \\
\text { archy }\end{array}$ & & 8 & 2 & 2 \\
\hline \multirow{2}{*}{$\begin{array}{l}\text { Incentives for personal } \\
\text { vote }\end{array}$} & Higher & & 5 & 1 & 1 \\
\hline & Lower & & 6 & 1 & 4 \\
\hline \multirow[t]{2}{*}{ Party systems } & $\begin{array}{l}\text { Two-party/moderate } \\
\text { multiparty }\end{array}$ & & 3 & 2 & 4 \\
\hline & Strong multiparty & & 8 & & 1 \\
\hline \multirow[t]{3}{*}{ Media systems } & Polarized pluralist & & 4 & & 1 \\
\hline & Democratic corporatist & & 7 & 1 & 2 \\
\hline & liberal & & & 1 & 1 \\
\hline
\end{tabular}

On Regime Type, (Semi-)Presidential includes Austria, Finland, France, Iceland, Ireland, and Portugal; Parliamentary/Monarchy includes Belgium, Denmark, Germany, Greece, Italy, the Netherlands, Norway, Spain, Sweden, Switzerland, and the United Kingdom

On Incentives for Personal Vote, Lower Incentives includes Austria, Belgium (Flanders and Wallonia), Denmark, Greece, Iceland, the Netherlands, Norway, Portugal, Spain, and Sweden; Higher Incentives includes Finland, France, Germany, Ireland, Italy, Switzerland, and the United Kingdom. Lower Incentives includes countries with an average value equal to or lower than 3, while Higher Incentives includes countries with an average higher than 3. Data come from Emanuele (2018)

On Party Systems, Two-party/Moderate multiparty includes Austria, Germany, Greece, Ireland, Norway, Portugal, Spain, Sweden, and the United Kingdom; Strong multiparty includes Belgium, Denmark, Finland, France, Iceland, Italy, the Netherlands, Norway, Sweden, and Switzerland. We have divided countries by taking inspiration from Sartori's threshold of 5 parties to distinguish party systems between those with limited pluralism and those with extreme pluralism (Sartori 1976 [2005]). Countries are categorized according to the average values of the Effective Number of Parties (ENEP). Data come from Gallagher (2019)

On Media Systems, Polarized Pluralist includes France, Greece, Italy, Portugal, Spain; Democratic Corporatist includes Austria, Belgium, Denmark, Finland, Germany, the Netherlands, Norway, Sweden, Switzerland; Liberal includes the United Kingdom and Ireland; Iceland has been excluded from Media Systems rows. Data come from Hallin and Mancini (2004)

personalization (18) and those disconfirming it or showing mixed evidence from one case to the other (22)' (Wauters et al. 2016, p. 513). So, finding differentiated results concerning the personalization of politics and its different facets is surely not unexpected.

Third, as already argued, in many cases, the strongest upwards or downwards movements occur in the Personalization in General Elections. As we move to the party-level dimensions, a significant number of polities show a negligible trend over time, especially in the Personalization in Party Control, with eight countries out of 16 reporting such a stability. If we look at Table 2, only Belgium (Flanders) and Italy show a strong increase in a party-level dimension of personalization, while no country shows a strong decrease. Clearly, we are comparing a country-level measure (the first PoPES dimension) with a weighted party-level average (the remaining 
PoPES dimensions), and this might help explain such differences-with contrasting party trends canceling each other.

Fourth, let us expand on the last point: in the Personalization in General Elections dimension, there are also some countries showing a de-politicization trend over time: Ireland, Greece, Austria, Sweden, and Iceland. In all such countries, the overall impact of personalization is lower in the mid-2010s than in the mid-to-late1980s. The fact that some countries experience 'depersonalization' (e.g., see Rahat and Kenig 2018, p. 8) reminds us that further research might be needed to investigate the specific reasons behind such differing trends across Western Europe.

Fifth, and finally, Table 3 above presents a synthetic overview of country trends of the Personalization in General Elections by different country-level features, to understand, even if from a merely descriptive viewpoint, if the latter can shed some light on the trends of the former.

We have selected four different country characteristics, partly following Rahat and Kenig (2018, pp. 202-203): regime type, dividing countries in (semi-)presidential and parliamentary/monarchy ones; the presence of higher or lower 'incentives to cultivate a personal vote' (Carey and Shugart 1995); the party system format (two-party or moderate multiparty and strong multiparty systems); the type of media systems. Interestingly, while it could have been imagined that presidential systems could have fostered positive trends concerning the general impact of personalization (e.g., see Adam and Maier 2010), Table 3 shows that, compared to parliamentary regimes and constitutional monarchies, among (semi-)presidential countries there is a higher proportion of polities where there is a decline (be it moderate or strong). Instead, a more imaginable differentiation is that between countries with higher or lower incentives for personal vote: in the former cases, there is a higher percentage case with an increase in the impact of personalization over time (in line with the argument by Adam and Maier 2010). Moreover, there seems to be a higher proportion of strong multiparty systems (see Table 3 for more details) where the impact of personalization has increased over time compared to two-party or moderate multiparty systems, in contrast with a general argument by McAllister (2007). Finally, and this is probably the most puzzling result, it does not matter whether countries have a 'polarized pluralist' or a 'democratic corporatist' media system (Hallin and Mancini 2004). Just the two 'liberal' media systems (Ireland and the United Kingdom) show a negligible trend or even a decrease in the impact of personalization over time. We are not sure about the precise possible mechanism at work here, but Table 3 further confirms that empirical research starting from PoPES data has many conundrums to solve. Before exploring some possible future research agendas, "Validation" section discusses the validation of PoPES data.

\section{Validation}

In this section, we use other works on the personalization of politics (or topics related to such process) to validate the results summarized in Table 2 and Figs. 1, 2 , and 3. To begin with, the overall results of the analysis by Rahat and Kenig (2018, pp. 220-221) can be of great help, even if we shall pay specific attention 
in comparing our results with theirs. First, Rahat and Kenig cover the 1960-2015 period, while the PoPES covers the 1985-2016 one. Second, they focus on a series of indicators and dimensions that are quite different from ours (Rahat and Kenig 2018, pp. 137-170), then summarized at the country level. Third, they report a general overview of the increase in the level of personalization of politics or, conversely, the increase in the level of depersonalization of politics with a five-point scale (Rahat and Kenig 2018, p. 8), later summarized by grouping countries in clusters according to their overall level of increase in (de)personalization (Rahat and Kenig 2018, pp. 201-202). Instead, the country-level question of the PoPES is related to the level of impact of personalization of politics. For all these reasons, a feasible strategy is generally comparing how our countries score compared to theirs to have an overall 'qualitative' snapshot.

Let us start with the countries showing similar trends in the PoPES and Rahat and Kenig's analysis. According to Rahat and Kenig, Italy has undergone a process of high personalization of politics, while in Belgium there has been a moderate personalization, in France, the Netherlands, and Spain there has been a low personalization, and no trend is detectable for the United Kingdom. Table 3 shows that, according to our experts, between the mid-1980s and the mid-2010s, in Italy, there has been a sharp increase in the impact of the personalization of politics, while in France, the Netherlands, and Spain there has been a much more moderate increase and, finally, the United Kingdom has not shown an overall increase or decrease in the impact of the personalization over time. The case of Belgium can be considered as compatible with the results of Rahat and Kenig because if we group the Flemish and the Walloon values in Table 3, the resulting trend is comparable with the moderate personalization reported by Rahat and Kenig for Belgium.

Then, there is a second group of countries where the country-level trend of the PoPES reported in Table 3 is only partially compatible with the results by Rahat and Kenig. For such countries, the sign of the increase/decrease in the (impact of) personalization is the same, while the movement's strength is different. To be clearer, for Rahat and Kenig, Denmark has experienced a moderate-low personalization, while Germany and Sweden a low personalization. For these countries, Table 3 reports a comparable trend as far as the (upwards or downwards) direction of the trend is concerned, while the strength of the movement of Denmark, Germany, and Sweden is different.

Finally, there is a third group of countries where even the sign of the personalization trend is different in the PoPES and Rahat and Kenig: Austria, Finland, Greece, Iceland, Ireland, Norway, Portugal, and Switzerland.

All in all, if we bear in mind all the differences between the country-level question of the PoPES and Rahat and Kenig's summary of their work, we can be at least partly satisfied by the comparison between the former and the latter studies.

A second, quantitative, validity test concerns the results related to the autonomy of party leaders in selecting candidates for general elections (see Figs. 1, 2, 
3 and Table 2). We have used the Comparative Candidate Survey (CCS) data for the 2005-2013 period (CCS 2016) and the 2013-2019 one (CCS 2020). For the 2005-2013 period, we have used the answers to two questions, B3a ('Who made the decision about your nomination?' ${ }^{15}$ ) and B3b ('At what level was the decision of your nomination made? ${ }^{16}$ ). Then, for the 2013-2019 period, we have used the answers to the question B3 ("Most influential in deciding on candidacy nomination ${ }^{17}$ ). For each party under consideration, we have calculated the percentage of respondents who declared to have been selected at the national level by the party leadership. ${ }^{18}$ The comparison between the PoPES and the CCS shall be made with caution. The PoPES and the CCS do not measure the same empirical object. The PoPES asked experts to measure the autonomy of party leaders in selecting candidates for general elections, while the CCS asked candidates to evaluate their selectorate and where their selection was made. So, not only is the set of people who were interviewed different (experts vs candidates), but also the questions asked to each set of people are different. So, we should be careful in 'precisely' comparing the PoPES and the CCS or safely validating the former with the latter.

The correlation analysis between the PoPES and the CCS returned a correlation coefficient equal to 0.54 , with a $p<0.001(N=90)$. In other words, the higher the autonomy of the party leader in selecting candidates for general elections reported by PoPES experts, the higher the proportion of candidates having indicated that their selection was made by the party leadership at the national level. Clearly, the p-value is a quite positive element in our reasoning, but the strength of the association indicates the correlation between the PoPES measure and the CCS measure is not perfect. Nonetheless, let us again consider the differences between the object measured by the PoPES and that measured by the CCS, and also the differences between PoPES interviewees (experts) and CCS interviewees (candidates). All in all, we can be reasonably satisfied by the validity test provided by CCS data.

A third quantitative test makes use of data by Schumacher and Giger (2017). In this case, their data can be used vis-à-vis PoPES data on the policy-making autonomy of party leaders. Indeed, starting from the replication material for their article published on Political Studies, we have used the measure of 'leadership domination'

\footnotetext{
15 Candidates could indicate 'voters at large,' 'voters of my party,' 'members of my party,' 'a party delegate conference,' 'party leadership,' 'candidate of the last campaign,' 'others' (besides not answering).

${ }^{16}$ Candidates could indicate 'at constituency level,' 'at regional/state/provincial level,' 'at national level,' 'at other level,' 'at other level' (besides not answering).

${ }^{17}$ Candidates could indicate 'open primary election,' 'supporters of my party (primary election), 'party members in my constituency,' 'party delegates in my constituency,' 'party leadership in my constituency,' 'national party leadership,' 'other' (besides not answering).

${ }^{18}$ More specifically, for each party in each general election under consideration, we have considered the percentage of respondents who had indicated, in the first wave, 'party leadership' as an answer to B3a and 'at national level' as an answer to B3b, and, in the second wave, 'national party leadership' as an answer to question B3. Concerning the first wave of the CCS, we have excluded from the calculation those respondents with a missing value on either $\mathrm{B} 3 \mathrm{a}$ or $\mathrm{B} 3 \mathrm{~b}$ and also only those respondents who had indicated 'at other level' for B3b: we included only those respondents who had indicated both the selectorate and the level of selection and also included only those respondents with an understandable level of selection.
} 
they have calculated from a series of sources. More specifically, we have used their measure derived from Laver and Hunt (1992) and Rohrschneider and Whitefield (2012): Schumacher and Giger 'constructed leadership domination indices that theoretically cover a range between -1 (activist-dominated) and 1 (leadership-dominated)' (Schumacher and Giger 2017, p. 169 [italics in original]) and concerns who determines or influences the party policy (ibidem). Clearly, given that Schumacher and Giger deal with expert surveys, we can be a little more confident in using their data vis-à-vis PoPES data for the autonomy of party leaders in selecting the policymaking agenda of their parties. On the other hand, there is an important point: the surveys used by Schumacher and Giger employ a dichotomy between the influence of the party leadership vs that of party activists in influencing the policy of a given party (for data derived from Laver and Hunt 1992) and a dichotomy between the strength of the party leadership vs the strength of the party membership in determining the party policy (for data derived from Rohrschneider and Whitefield 2012). So, the questions used by Schumacher and Giger are different from those implemented in the PoPES (which asked respondents to rate the autonomy of the party leader in determining the policy-making agenda of the party, without mentioning other intraparty groups). This does not mean we cannot use their data as a validity check, but we shall be careful in performing such check and evaluate data with caution.

The correlation coefficient between PoPES data and Schumacher and Giger's data is equal to $0.48, p<0.001(N=72)$. Again, the p-value and the positive sign of the coefficient indicate that the higher evaluation by PoPES experts of the autonomy of party leaders in determining the policy-making agenda of their parties, the higher the score of parties reported by Schumacher and Giger on their- $1 /+1$ scale. Nonetheless, the magnitude of the coefficient indicates a not very high association between the two measures. All in all, considering the differences between our data and theirs, we can be at least partly satisfied with such a test.

\section{Conclusions}

In this article, we have presented some data collected thanks to an expert survey on the personalization of politics (PoPES, Personalization of Politics Expert Survey) in Western Europe in the past few decades. Experts have answered questions on more than 110 political parties and a series of Western European countries from 1985 until 2016. In this article, we have focused on four dimensions: the general impact of the personalization of politics in each country; the autonomy of party leaders in selecting candidates for general elections; the autonomy of party leaders in defining the policy-making agenda of their parties; and the control of party organizations by their leaders. To the best of our knowledge, this is the first time that such finegrained diachronic data are presented. This means it is possible to precisely grasp the temporal evolution of personalization both at the country and the party level.

We have devoted much attention to show data in a descriptive manner and have done so for a specific reason. Before delving deeper into more complex analyses on the personalization of politics, we contend that a first necessary step is to explore the added value and importance of our research endeavor. 
After having discussed the building of the expert survey in "From concepts to variables: devising the expert survey," "The PoPES questions" sections has shown four questions of the PoPES, before moving, in "A first view of the data: trends of the personalization of politics in Western Europe (mid-1980s-mid-2010s)" section, to present the evolution of the four abovementioned dimensions in different country groups, with quite interesting results: it is not possible to identify a clear trend of the personalization of politics among Western European countries, while country- or dimension-related differences can be easily detected. Finally, "Validation" section has discussed the validation of the PoPES with the help of well-known pieces of research on the personalization of politics, candidate selection, and parties' policy-making.

In a nutshell, in this article, we have shown there is a compound system of interactions among different dimensions of the personalization of politics, which will surely deserve the attention of comparative scholars to be fully understood.

This article has some limitations as well. To begin with, as already shown above, there are no data available for some countries, especially in Scandinavia, while, in other cases (e.g., Walloon parties), it was not possible to obtain data for more than one point in time. We hope that future research might fill this gap and thus contribute widening our understanding of important faces of the personalization of politics.

Moreover, the clear focus of this article is on party leaders, one of the facets of the 'centralized personalization' (Balmas et al. 2014). As a consequence, other aspects of this phenomenon have been left out. We hope that, by implementing and ameliorating the framework reported in this article, scholars can add further layers to ours, such as the media one or the parliamentary and governmental one. Moreover, certain attention could be devoted to other power-holders, such as candidates to general elections or Members of Parliament, to encompass both the 'centralized' and the 'decentralized' aspects of the personalization of politics (Balmas et al. 2014). Indeed, nothing blocks researchers from adding further dimensions of analysis to the ones we have presented in this article, to reach an even wider comprehension of this phenomenon from a cross-time or simply a cross-country perspective.

Researchers could use our data for further analyses as well. For instance, understanding the determinants of one or more faces of the personalization of politics in Western Europe (Adam and Maier 2010; Rahat and Kenig 2018): what are the drivers of leaders' increased control of their party organizations? Then, are scholars right to argue that different institutional incentives can affect the levels of personalization of politics? These are just two of the many questions that can be answered by using PoPES data. At the same time, the variables presented in this article can also be used as independent factors: is it true that the personalization of politics could influence party change (Rahat and Kenig 2018)? Could MPs' legislative behavior be affected by party leaders' autonomy in selecting the policy-making agenda of their parties? And so on.

All these implications, here summarized in a nutshell, probably represent the most ambitious prospect derived from our contribution and show the potential added value of PoPES data for a broad area of studies. 
Supplementary Information The online version contains supplementary material available at https://doi. org/10.1057/s41269-021-00210-x.

Acknowledgements A preliminary report of PoPES data, including information on countries, data, and reliability tests, appeared as a University of Siena's CIRCaP Occasional Paper (Second Series) (n. 4/2018). We wish to thank Diego Garzia, Piero Ignazi, and Ferdinand Müller-Rommel for their comments during the development of this project.

Funding Open access funding provided by Università degli Studi di Siena within the CRUI-CARE Agreement.

Open Access This article is licensed under a Creative Commons Attribution 4.0 International License, which permits use, sharing, adaptation, distribution and reproduction in any medium or format, as long as you give appropriate credit to the original author(s) and the source, provide a link to the Creative Commons licence, and indicate if changes were made. The images or other third party material in this article are included in the article's Creative Commons licence, unless indicated otherwise in a credit line to the material. If material is not included in the article's Creative Commons licence and your intended use is not permitted by statutory regulation or exceeds the permitted use, you will need to obtain permission directly from the copyright holder. To view a copy of this licence, visit http://creativecommons.org/licen ses/by/4.0/.

\section{References}

Adam, S., and M. Maier. 2010. Personalization of politics: A critical review and agenda for research. Annals of the International Communication Association 34 (1): 213-257.

Andeweg, R.B., and J. Thomassen. 2011. Pathways to party unity: Sanctions, loyalty, homogeneity and division of labour in the Dutch parliament. Party Politics 17 (5): 655-672.

Aylott, N., and N. Bolin. 2007. Towards a two-party system? The Swedish parliamentary election of September 2006. West European Politics 30 (3): 621-633.

Bakker, R., C. de Vries, E. Edwards, L. Hooghe, S. Jolly, G. Marks, J. Polk, J. Rovny, M. Steenbergen, and M.A. Vachudova. 2015. Measuring party positions in Europe: The Chapel Hill expert survey trend file, 1999-2010. Party Politics 21 (1): 143-152.

Balmas, M., G. Rahat, T. Sheafer, and S.R. Shenhav. 2014. Two routes to personalized politics: Centralized and decentralized personalization. Party Politics 20 (1): 37-51.

Benoit, K., and M. Laver. 2006. Party policy in modern democracies. Abingdon: Routledge.

Blondel, J. 1987. Political leadership-Towards a general analysis. London: Sage.

Blondel, J. 1996. Britain: a textbook case of government-supporting party relationship. In Party and government, ed. J. Blondel and M. Cotta, 22-39. Basingstoke: Palgrave Macmillan.

Blondel, J., and M. Cotta, eds. 2000. The nature of party government. Basingstoke: Palgrave Macmillan.

Blondel, J., and J.-L. Thiébault. 2010. Political leadership, parties and citizens. Abingdon: Routledge.

Borz, G., and C. De Miguel. 2019. Organizational and ideological strategies for nationalization: Evidence from European Parties. British Journal of Political Science 49 (4): 1499-1526.

Bosco, A., and L. Morlino. 2006. What changes in South European Parties? A comparative introduction. South European Society and Politics 11 (3-4): 331-358.

Calise, M. 2005. Presidentialization, Italian Style. In The presidentialization of politics, ed. T. Poguntke and P. Webb, 88-106. Oxford: Oxford University Press.

Carey, J., and M.S. Shugart. 1995. Incentives to cultivate a personal vote: A rank ordering of electoral formulas. Electoral Studies 14 (4): 417-439.

CCS. 2016. Comparative Candidates Survey Module I-2005-2013 [Dataset-cumulative file]. Distributed by FORS, Lausanne, 2016. https://doi.org/10.23662/FORS-DS-620-3.

CCS. 2020. Comparative Candidates Survey Wave II-2013-2019 [Dataset-cumulative file]. Distributed by FORS, Lausanne, 2020. https://doi.org/10.23662/FORS-DS-886-4.

Chiaramonte, A., and V. Emanuele. 2017. Party system volatility, regeneration and de-institutionalization in Western Europe (1945-2015). Party Politics 23 (4): 376-388. 
Costa Lobo, M. 2005. The presidentialization of portuguese democracy? In The presidentialization of politics, ed. T. Poguntke and P. Webb, 269-288. Oxford: Oxford University Press.

Costa Lobo, M. 2018. Personality goes a long way. Government and Opposition 53 (1): 159-179.

Cotta, M., and L. Verzichelli. 2014. The development of political elites in Europe. In The Routledge handbook of European politics, ed. J.M. Magone, 421-438. Abingdon: Routledge.

De Winter, L., R. Karlsen, and H. Schmitt, eds. 2021. Parliamentary candidates between voters and parties. Abingdon and New York: Routledge.

Dowding, K. 2013a. The prime ministerialisation of the British Prime Minister. Parliamentary Affairs 66: 617-635.

Dowding, K. 2013b. Beneath the surface: Replies to three critics. Parliamentary Affairs 66 (3): 663-672.

Dowding, K., and P. Dumont, eds. 2009. The selection of ministers in Europe: Hiring and firing. Abingdon: Routledge.

Druckman, J.N., and P.V. Warwick. 2005. The missing piece: Measuring portfolio salience in Western European parliamentary democracies. European Journal of Political Research 44 (1): 17-42.

Emanuele, V. 2018. Cleavages, institutions and competition. London and New York: Rowman and Littlefield International/ECPR Press.

Emanuele, V., and A. Chiaramonte. 2018. A growing impact of new parties: Myth or reality? Party system innovation in Western Europe after 1945. Party Politics 24 (5): 475-487.

Farrell, D. 1996. Campaign strategies and tactics. In Comparing democracies: Elections and voting in global perspective, ed. L. LeDuc, R.G. Niemi, and P. Norris, 158-181. London: Sage.

Fiers, S., and A. Krouwel. 2005. The low countries: from "prime minister" to "president-minister." In The presidentialization of politics, ed. T. Poguntke and P. Webb, 128-158. Oxford: Oxford University Press.

Gallagher, M. 2019. Electoral Systems web site. https://www.tcd.ie/Political_Science/people/michael_ gallagher/ElSystems/index.php.

Gallagher, M., and M. Marsh. 1988. Candidate selection in comparative perspective: The secret garden of politics. London: Sage.

Hallin, D.C., and P. Mancini. 2004. Comparing media systems. Cambridge: Cambridge University Press.

Hazan, R.Y., and G. Rahat. 2010. Democracy within parties. Oxford: Oxford University Press.

Heffernan, R., and P. Webb. 2005. The British Prime Minister: much more than "first among equals." In The presidentialization of politics, ed. T. Poguntke and P. Webb, 26-62. Oxford: Oxford University Press.

Janda, K. 1980. Political parties: A cross-national survey. New York: Free Press.

Karvonen, L. 2010. The personalisation of politics. Colchester: ECPR Press.

Katz, R.S., and P. Mair. 1993. The evolution of party organizations in Europe: The three faces of party organization. American Review of Politics 14 (4): 593-617.

Katz, R.S., and P. Mair, eds. 1994. How parties organize. London: Sage.

Kölln, A.-K. 2016. Party membership in Europe: Testing party-level explanations of decline. Party Politics 22 (4): 465-477.

Kriesi, H. 2011. Personalization of national election campaigns. Party Politics 18 (6): 825-844.

Langer, A.I., and I. Sagarzazu. 2018. Bring back the party: Personalisation, the media and coalition politics. West European Politics 41 (2): 472-495.

Laver, M., and W.B. Hunt. 1992. Policy and party competition. London: Routledge.

Mainwaring, S., and T.R. Scully. 1995. Building democratic institutions: Party systems in Latin America. Stanford: Stanford University Press.

Mazzoleni, G. 1996. Patterns and effects of recent changes in electoral campaigning in Italy. In Politics, media, and modern democracy: An international study of innovations in electoral campaigning and their consequences, ed. D.L. Swanson and P. Mancini, 193-206. Greenwood: Westport.

McAllister, I. 2007. The personalization of politics. In The Oxford Handbook of Political Behaviour, ed. R.J. Dalton and H.-D. Klingemann, 571-588. Oxford: Oxford University Press.

Mughan, A. 2000. Media and the presidentialization of parliamentary elections. Basingstoke: Palgrave Macmillan.

Musella, F. 2018. Political leaders beyond party politics. Basingstoke: Palgrave Macmillan.

Musella, F., and P. Webb. 2015. The revolution of personal leaders. Italian Political Science Review/rivista Italiana Di Scienza Politica 45 (3): 223-226.

Nanou, K., G. Zapryanova, and F. Toth. 2017. An ever-closer union? Measuring the expansion and ideological content of European Union policy-making through an expert survey. European Union Politics 18 (4): 678-693. 
Norris, P., ed. 1997. Passages to power: Legislative recruitment in advanced democracies. Cambridge: Cambridge University Press.

O’Malley, E. 2007. The power of prime ministers: Results of an expert survey. International Political Science Review 28 (1): 7-27.

Paloheimo, H. 2005. Finland: let the force be with the leader-but who is the leader? In The presidentialization of politics, ed. T. Poguntke and P. Webb, 246-268. Oxford: Oxford University Press.

Pappas, T.S., and E. Dinas. 2006. From opposition to power: Greek conservatism reinvented. South European Society and Politics 11: 477-495.

Pilet, J.-B., and W.P. Cross, eds. 2014. The selection of political party leaders in contemporary parliamentary democracies. London and New York: Routledge.

Poguntke, T. 2005. A presidentializing party state? The Federal Republic of Germany. In The presidentialization of politics, ed. T. Poguntke and P. Webb, 63-87. Oxford: Oxford University Press.

Poguntke, T., and P. Webb, eds. 2005a. The presidentialization of politics. Oxford: Oxford University Press.

Poguntke, T., and P. Webb. 2005b. The presidentialization of politics in democratic societies: A framework for analysis. In The presidentialization of politics, ed. T. Poguntke and P. Webb, 1-25. Oxford: Oxford University Press.

Poguntke, T., and P. Webb. 2018. Presidentialization, personalization and populism: The hollowing out of party government. In The personalization of democratic politics and the challenge for political parties, ed. W.P. Cross, R.S. Katz, and S. Pruysers, 181-196. London and New York: Rowman and Littlefield International / ECPR Press.

Pruysers, S., W.P. Cross, and R.S. Katz. 2018. Personalism, personalization and party politics. In The personalization of democratic politics and the challenge for political parties, ed. W.P. Cross, R.S. Katz, and S. Pruysers, 1-18. London and New York: Rowman and Littlefield International / ECPR Press.

Rahat, G., and O. Kenig. 2018. From party politics to personalized politics? Party change and political personalization in democracies. Oxford: Oxford University Press.

Rahat, G., and T. Sheafer. 2007. The personalization(s) of politics: Israel, 1949-2003. Political Communication 24 (1): 65-80.

Ray, L. 1999. Measuring party orientations towards European integration: Results from an expert survey. European Journal of Political Research 36 (2): 283-306.

Renwick, A., and J.-B. Pilet. 2016. Faces on the Ballot: The personalization of electoral systems in Europe. Oxford: Oxford University Press.

Rohrschneider, R., and S. Whitefield. 2012. The strain of representation: How parties represent diverse voters in Western and Eastern Europe. Oxford: Oxford University Press.

Samuels, D.J., and M.S. Shugart. 2010. Presidents, parties, and Prime Ministers. How the separation of powers affects party organization and behavior. Cambridge: Cambridge University Press.

Sartori, G. 1976 [2005]. Parties and Party Systems. Colchester: ECPR Press.

Scarrow, S.E., P.D. Webb, and T. Poguntke, eds. 2017. Organizing political parties. Oxford: Oxford University Press.

Schumacher, G., and N. Giger. 2017. Who leads the party? On membership size, selectorates and party oligarchy. Political Studies 65 (1): 162-181.

Schumacher, G., C.E. de Vries, and B. Vis. 2013. Why do parties change position? Party organization and environmental incentives. The Journal of Politics 75 (2): 464-477.

Spies, D.C., and A. Kaiser. 2014. Does the mode of candidate selection affect the representativeness of parties? Party Politics 20 (4): 576-590.

Spourdalakis, M., and C. Tassis. 2006. Party change in Greece and the vanguard role of PASOK. South European Society and Politics 11 (3-4): 497-512.

Strøm, K., W.C. Müller, and T. Bergman, eds. 2003. Delegation and accountability in parliamentary democracies. Oxford: Oxford University Press.

Van Aelst, P., T. Sheafer, and J. Stanyer. 2012. The personalization of mediated political communication: A review of concepts, operationalizations and key findings. Journalism: Theory, Practice \& Criticism 13 (2): 203-220.

Van Biezen, I., and J. Hopkin. 2005. The presidentialization of Spanish democracy: sources of Prime Ministerial power in Post-Franco Spain. In The presidentialization of politics, ed. T. Poguntke and P. Webb, 107-126. Oxford: Oxford University Press.

Van Haute, E., E. Paulis, and V. Sierens. 2018. Assessing party membership figures: The mapp dataset. European Political Science 17 (3): 366-377. 
Wauters, B., N. Bouteca, and B. De Vet. 2021. Personalization of parliamentary behaviour: Conceptualization and empirical evidence from Belgium (1995-2014). Party Politics 27 (2): 246-257.

Wauters, B., P. Thijssen, and P. Van Aelst. 2016. Centralized personalization at the expense of decentralized personalization. The decline of preferential voting in Belgium (2003-2014). Party Politics 24 (5): 511-523.

Webb, P.D., and T. Poguntke. 2005. The presidentialization of politics in democratic societies: evidence, causes, and consequences. In The presidentialization of politics, ed. T. Poguntke and P. Webb, 336355. Oxford: Oxford University Press.

Webb, P., and T. Poguntke. 2013. The presidentialisation of politics thesis defended. Parliamentary Affairs 66: 646-654.

Publisher's Note Springer Nature remains neutral with regard to jurisdictional claims in published maps and institutional affiliations. 